\title{
Explaining the Consumer Decision-Making Process: Critical Literature Review
}

\author{
Alina Stankevich \\ The Faculty of Behavioural, Management and Social sciences (BMS), University of Twente, Enschede, the Netherlands
}

\section{ABSTRACT}

2017 Research Leap/Inovatus Services Ltd. All rights reserved.

DOI: 10.18775/jibrm.1849-8558.2015.26.3001

URL: http://dx.doi.org/10.18775/jibrm.1849. 8558.2015.26.3001

\section{Keywords:}

Decision-making process, Consumer behaviour, Buying behaviour, Model of decision-making

\begin{abstract}
In the last years, research investigating consumer behaviour and how their decision-making process has advanced and has become an important topic in the marketing society and literature. To advance the research further, this paper presents an extensive literature review of academic publications in the area of buying decision-making process in marketing and its status. Furthermore, the paper presents latest trends and themes that emerge there. Based on 24 journal articles, reports and marketing books, the core models and theories in this area were evaluated and discussed. Moreover, a framework of "moments that matter" in consumer decision-making process and factors that influence them was elaborated for a possibility to influence consumer behaviour in favour of company's offers. Furthermore, recommendations for marketers were suggested for deeper understanding the consumer behaviour and their buying strategies to empower marketing campaigns and be a success in the market. The paper also suggests several directions for future research related to buying behaviour.
\end{abstract}

\section{Introduction}

"All marketing decisions are based on assumptions and knowledge of consumer behaviour."

(Hawkins, Mothersbaugh \& Best, 2007)

The consumer behaviour has always been a hot marketing topic, due to the fact that knowing how and why consumers act in a certain way making their buying decisions helps companies improve their marketing strategies and be more successful on the market. Thus, a challenge faced by all marketers today is how to influence the purchase behaviour of consumers in favour of their products or services. Therefore, the knowledge of buying behaviour sheds the light on the psychology of how consumers think, feel, argument and select among existing alternatives (e.g., brands, products, and retailers), also how the consumer's environment (e.g., culture, family, media) influences him/her, additionally, how consumer motivation and decision strategies distinct between products. That's all lead to understanding - how marketers can improve their marketing campaigns to more effectively reach the consumer.

This research paper focuses on consumer buying behaviour, specifically on factors/moments that influence customers' decision-making process. Research questions are (1) What are the "moments that matter" in consumer decision-making process? (2) What factors are expected to influence the "moments that matter" in this process?

The research paper is a literature review of main trends, theories, and gaps in the field of buyer behaviour. Moreover, a framework of the factors that influence each step of the decision-making process will be presented and discussed. At the end recommendations for the further research in this area will be suggested.

The subject of buying decision-making was chosen due to the several reasons. First of all, every person is playing a role of a consumer and makes a lot of purchase decisions every day. It is important to understand what is influencing personal buying decisions - is it a problem/need or a well-thought professional marketing campaign. Besides that, from a marketer perspective, it is valuable to know this topic in order to effectively target customers, improve products and services of a company, and understand how customers view products versus competitors' products. That is all result in providing value and customer satisfaction, creating a competitive advantage and enhancing the value of the company.

Back to XX century scholars were thinking and proposing general theories and extended frameworks in the sphere of consumer behaviour. Nowadays, researchers investigate particular determinants and specific relationships; also more complex questions arise involving other sciences as, for example, neuroscience. As a result, new fields of science appear, a good example of this is neuromarketing. Neuromarketing investigates how human's brain works and reacts to marketing stimuli, applying the principles of neuroscience to marketing research.

Trends in consumer behaviour also change over years. In a fast-moving word today people expect things to do not only that involves interacting with all their senses, but also offer a range of new touch points and what involves entirely in new experiences. There is an increasing desire for multiplicity and experiences are expected to offer more. It is no longer 
enough to immerse the observer in an experience, and people are rejecting the idea of passive on looking. They desire now active participation.

Multiplicity leads to the need for hyper-efficiency. People are looking for and finding smarter and more efficient ways to solve their problems. People are using every last piece of space and time; people are seeking smart ways to integrate a range of functions into one property.

Additionally, consumers have tasted super-personalization. New technology means being able to read consumers and give them what they want - sometimes without even asking them ("Six Trends That Will Shape Consumer Behavior This Year", 2014). Advanced technologies are the part of people lives and being constantly online is a status quo, so happens with buying behaviour, people are switching to e-commerce and marketers have to take into account.

What is more, nowadays consumers care about the global resources and community and want to know that the brands they purchase from doing so too. In 2016 and onwards, it sees more businesses align with environmental and social causes to appeal to increasing pressure for brands to authentically stand for something greater than the products they sell (Walsh, 2016).

Also, today is crucial to take into consideration the characteristics of current generation - Millennials. They are key social media audience that isn't easily influenced by social media as 48 percent claim that social media has never influenced their purchase decisions. Millennials tend to consume content on various platforms through different devices and are typically highly influenced by what their peers think. So for marketers, it is important to understand how this demographic consumes information and second, how to deliver the right marketing message that appeals to them (Johson W., 2014).

Marketing has one goal - to reach consumers at the moments that most influence their decisions when consumers are open to influence, so-called "moments that matter" or "touch points". Marketers are always seeking those moments. For years, touch points have been understood through the metaphor of a "funnel" (Figure 1).
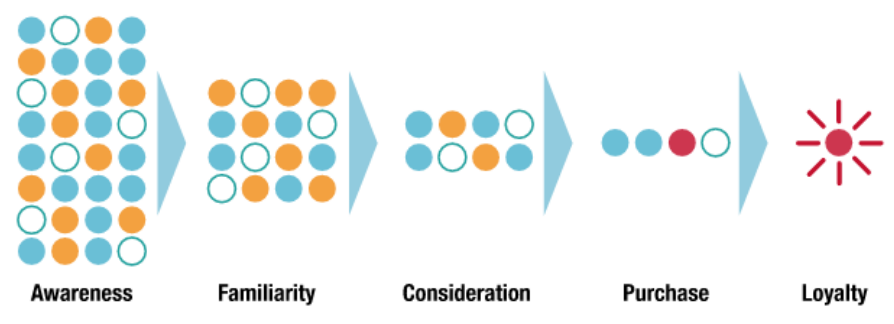

Consideration

Purchase

Loyalty

Figure 1: The Traditional Funnel

Consumers start with some potential brands in mind (left side of the funnel), then marketing directs them and consumers reduce that number of brands and move through the funnel, and to the end, they arrive with the one brand they chose to purchase (right end of the funnel).

But today, the funnel concept fails to capture all the touch points and key buying factors resulting from the explosion of product choices and digital channels, coupled with the evolution of an increasingly well-informed consumer. A more sophisticated approach is required to help marketers guide through this environment, which is more complicated than the funnel suggests. McKinsey found that because the communication has been changed from one-way - marketers to consumers - toward a twoway communication - marketers to consumers and consumers to marketers - marketers need a systematic way to satisfy consumer demand and manage word-of-mouth (Court et al., 2009).

Talking about themes that emerge today, it is important to mention about creating connections with clients. Understanding the shopping experience can help companies identify additional consumer-connection moments before, during, and after the purchase. For instance, when consumers decided on a purchase, the marketer's work has just begun. A lot of consumers go online to run further research after the purchase. The postsale experience influences their opinion for every subsequent decision, so it is an ongoing cycle. Besides, understanding the consumer moments (e.g., the underlying values) provides companies with the opportunity to make these consumer engagement moments meaningful and memorable.

\section{Theory Background}

In this chapter of the research paper core theories and models in the field of consumer behaviour and buying decision-making will be discussed and evaluated. Different concepts and points of view will be presented by the scholars of the XX and XXI centuries.

To start with it is necessary to define the term "consumer behaviour". Business Dictionary offers the following definition. "Consumer buying behaviour is the process by which individuals search for, select, purchase, use, and dispose of goods and services, in satisfaction of their needs and wants". Also in many research articles, authors use the next definition. "Consumer behaviour is the study of individuals, groups, or organizations and the processes they use to select, secure, use, and dispose of products, services, experiences, or ideas to satisfy needs and the impacts that these processes have on the consumer and society."

Table 1: Decision-making Models

\begin{tabular}{|l|l|l|}
\hline $\begin{array}{l}\text { Name of the } \\
\text { Model }\end{array}$ & $\begin{array}{l}\text { Authors, } \\
\text { Year }\end{array}$ & Short description \\
\hline Simon model & $\begin{array}{l}\text { Simon H., } \\
1960\end{array}$ & $\begin{array}{l}\text { This model conceptualises the } \\
\text { decision-making process in } \\
\text { three stages of activities: } \\
\text { intelligence activity, design } \\
\text { activity, and choice activity. } \\
\text { Simon argues that decision- } \\
\text { making is a cognitive process } \\
\text { that can be separated into } \\
\text { simple, sequential steps. }\end{array}$ \\
\hline Nicosia model & $\begin{array}{l}\text { Nicosia F.M., } \\
1966\end{array}$ & $\begin{array}{l}\text { This model concentrates on } \\
\text { the communication process } \\
\text { that occurs between a brand } \\
\text { and a consumer. It uses a flow } \\
\text { of events through different } \\
\text { stages that are identified as } \\
\text { fields. }\end{array}$ \\
\hline $\begin{array}{l}\text { Engel, Kollat \& } \\
\text { Blackwell model }\end{array}$ & $\begin{array}{l}\text { Engel J.F., } \\
\text { Kollat D.T., } \\
\text { and } \\
\text { Blackwell } \\
\text { R.D., 1968 } \\
\text { The components of this } \\
\text { consumer model's decision } \\
\text { process are the following - } \\
\text { input, information processing, } \\
\text { decision process, and variables } \\
\text { influencing the decision } \\
\text { process. The decision process } \\
\text { component consists of five }\end{array}$ \\
\hline
\end{tabular}




\begin{tabular}{|c|c|c|}
\hline & & $\begin{array}{l}\text { following stages }- \text { need } \\
\text { recognition, search, alternative } \\
\text { evaluation, purchase, and } \\
\text { outcomes. }\end{array}$ \\
\hline $\begin{array}{l}\text { Theory of buyer } \\
\text { behaviour }\end{array}$ & $\begin{array}{l}\text { Sheth J. \& } \\
\text { Howard J.A., } \\
1969\end{array}$ & $\begin{array}{l}\text { The theory explains the buyer } \\
\text { behaviour of individuals over } \\
\text { a period. More specifically - } \\
\text { the brand choice behaviour of } \\
\text { the buyer. The authors identify } \\
\text { the elements of consumer } \\
\text { decision process (a set of } \\
\text { motives; several alternative } \\
\text { courses of action, and decision } \\
\text { mediators by which the } \\
\text { motives are matched with the } \\
\text { alternatives), observed the } \\
\text { changes that occur in them } \\
\text { over time as a result of their } \\
\text { repetitive nature and showed } \\
\text { how a combination of decision } \\
\text { elements affects search } \\
\text { processes and the } \\
\text { incorporation of information } \\
\text { from the buyer's commercial } \\
\text { and social environment. This } \\
\text { model suggests three levels of } \\
\text { consumer decision-making: } \\
\text { extensive problem solving } \\
\text { limited problem solving, and } \\
\text { habitual response behaviour. }\end{array}$ \\
\hline $\begin{array}{l}\text { An alternative } \\
\text { conceptualization } \\
\text { for consumer } \\
\text { behaviour and } \\
\text { product } \\
\text { performance }\end{array}$ & $\begin{array}{ll}\text { Narayana } & \\
\text { C.L. \& \& } \\
\text { Markin R.J., } \\
1975\end{array}$ & $\begin{array}{l}\text { The authors explain consumer } \\
\text { behaviour by describing the } \\
\text { term "evoked set" by } \\
\text { including and classifying all } \\
\text { the brands that may be in the } \\
\text { consumer's "awareness set", } \\
\text { inert, and inept set. They } \\
\text { presented a conceptual } \\
\text { framework for probable } \\
\text { consumer behaviour when } \\
\text { faced with a multiplicity of } \\
\text { brands. }\end{array}$ \\
\hline Mintzberg model & $\begin{array}{l}\text { Mintzberg } \\
\text { H., } \\
\text { Raisinghani } \\
\text { D. \& Theoret } \\
\text { A., } 1976\end{array}$ & $\begin{array}{l}\text { The key premise of this model } \\
\text { is that a basic structure } \\
\text { underlies these "unstructured" } \\
\text { processes. }\end{array}$ \\
\hline $\begin{array}{l}\text { Keeney's four- } \\
\text { stage decision- } \\
\text { making model }\end{array}$ & $\begin{array}{l}\text { Keeney R.L., } \\
1982\end{array}$ & $\begin{array}{l}\text { This four-stage model takes a } \\
\text { staged approach: Structure the } \\
\text { decision problem (generation } \\
\text { of alternatives and } \\
\text { specification of objectives), } \\
\text { assess possible impacts of } \\
\text { each alternative, determine } \\
\text { preferences (values) of } \\
\text { decision makers, and evaluate } \\
\text { and compare alternatives. This } \\
\text { model depicts the anticipated } \\
\text { complexities at each stage. }\end{array}$ \\
\hline
\end{tabular}

\begin{tabular}{|c|c|c|}
\hline $\begin{array}{l}\text { Rassuli \& Harrell } \\
\text { model }\end{array}$ & $\begin{array}{l}\text { Rassuli K.M. } \\
\& \quad \text { Harrell } \\
\text { G.D., } 1990\end{array}$ & $\begin{array}{l}\text { The perspective proposed here } \\
\text { is that choice and purchase can } \\
\text { be viewed as inputs into a } \\
\text { process, not merely the end of } \\
\text { consumer decision-making } \\
\text { efforts. In this way, one } \\
\text { recognizes the feedback, from } \\
\text { choice to other consumer- } \\
\text { behaviour variables. }\end{array}$ \\
\hline $\begin{array}{l}\text { Sheth, Newman } \\
\text { \& Gross model }\end{array}$ & $\begin{array}{l}\text { Sheth J.N., } \\
\text { Newman B.I. } \\
\& \text { Gross } \\
\text { B.L., } 1991\end{array}$ & $\begin{array}{l}\text { This model presents five } \\
\text { consumption values } \\
\text { influencing consumer choice } \\
\text { behaviour: functional, social, } \\
\text { conditional, emotional, and } \\
\text { epistemic values. Any or all of } \\
\text { the five consumption values } \\
\text { may influence the decision. }\end{array}$ \\
\hline $\begin{array}{l}\text { Smith \& Rupp's } \\
\text { model }\end{array}$ & $\begin{array}{l}\text { Smith } \\
\text { A. \& } \\
\text { Rupp } \\
2003\end{array}$ & $\begin{array}{l}\text { This model is an Internet- } \\
\text { based model that takes into } \\
\text { account external influences of } \\
\text { website marketing, the socio- } \\
\text { cultural environment, and } \\
\text { psychological issues on online } \\
\text { consumer tasks which is } \\
\text { followed by to a purchase and } \\
\text { post-purchase behaviour. }\end{array}$ \\
\hline $\begin{array}{l}\text { The Marketing } \\
\text { Spiral }\end{array}$ & $\begin{array}{l}\text { Armano D., } \\
2007\end{array}$ & $\begin{array}{l}\text { Consumer behaviour is like a } \\
\text { spiral that begins with an } \\
\text { interaction as opposed to } \\
\text { communication. The spiral } \\
\text { amplifies as the consumer } \\
\text { increases engagement. }\end{array}$ \\
\hline $\begin{array}{l}\text { McKinsey's } \\
\text { dynamic model } \\
\text { of the consumer } \\
\text { decision journey }\end{array}$ & $\begin{array}{lr}\text { Court } & \text { D., } \\
\text { Elzinga } & \text { D., } \\
\text { Mulder } & \text { S. \& } \\
\text { Vetnik } & \text { O.J., } \\
2009 & \end{array}$ & $\begin{array}{l}\text { This model is more circular } \\
\text { that sequential and has four } \\
\text { primary phases: initial } \\
\text { consideration; active } \\
\text { evaluation, or the process of } \\
\text { researching potential } \\
\text { purchases; closure, when } \\
\text { consumer buy brands; and } \\
\text { post-purchase, when } \\
\text { consumer experience them. }\end{array}$ \\
\hline
\end{tabular}

Consumer behaviour is the process consumers experience when they make purchases, and it involves factors that influence their decision. For many products and services, purchase decisions are the result of a long, detailed process that may include a broad information search, brands comparison, and evaluation. Marketers' success in influencing purchase behaviour depends to a large extent on how well they understand consumer behaviour. Marketers need to know the specific needs customers try to satisfy and how they turn it into purchase attributes. They need to understand how consumers gather information about different alternatives and use this information to select among competing brands (Belch G. \& Belch M., 2009).

\subsection{Decision-Making Models}

One of the most active academic research spheres in marketing over the past decades has been behavioural decision theory. Behavioural decision theorists have identified many situations in which consumers make irrational choices. What all these and other studies emphasise is that consumer behaviour is very valuable and the context of decisions is really 
important. Understanding how these effects manifest in the marketplace can be crucial for marketers. The work of these and other scholars have also challenged predictions from economic theory and assumptions about rationality, leading to the appearance of the field of behavioural economics. In Table 1, the key models are shortly presented starting from 1960 till nowadays.

\subsection{Traditional Model of Decision-Making}

The traditional model of consumer decision-making process "Five-stage model of the consumer buying process" (Figure 2) involves five steps that consumers move through when buying a product or service. A marketer has to understand these steps to properly move the consumer to the buying the product, communicate effectively to consumers and close the sale.

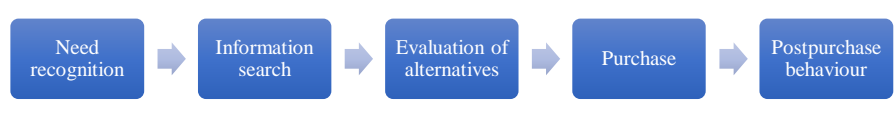

Figure 2: Five-stage model of the consumer buying process

For example, Kotler \& Keller (2012) in their book describe this model in details and explain additional stage of the model - disposal stage. Also, they discuss Moderating effects on consumer decision-making (like consumer involvement).

Belch G. \& Belch M. (2009) went further and discussed relevant internal psychological processes for each stage of the model (Figure 3)

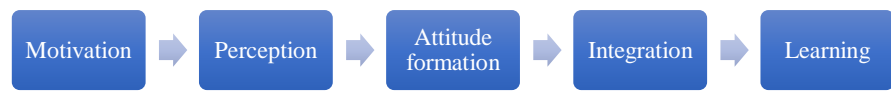

Figure 3: Internal Psychological Processes

Hereafter for each stage of the model the "moments that matter" and factors that influence them will be identified and discussed. Moreover, a self-developed framework about factors and their influences on relevant moments for consumers will be introduced with the aim of making a better understanding of the process and how and when it is a good time to interrupt it with a promotion. Later on, research of other scholars about factors that affect decision-making will be presented for having a broader view of the topic.

The very first stage of the model is need/problem recognition when consumers realize that they need something. Interestingly, marketers want to create intentionally an imbalance between consumers' present status and their preferred status. This imbalance will create a need and make consumers detect and buy a product or service. A need can occur immediately and can be a very basic impulse - this is called an internal stimulus. An external stimulus is when a person is affected by outside influences. Marketers create an imbalance/need by using advertising and sales promotions. When consumers recognize an unfulfilled need and that a product will satisfy it, they have created a want.

On this stage for marketers it is important to determine when their target demographic develops these needs/wants, therefore, it would be an ideal time to advertise to them. Marketers may also help to recognize the consumer's need/problem or circumstances that trigger a need/want.
Moreover, marketers may create the circumstance/need by themselves to make the consumer feel insecure without this product or create a desired status for customers.

Factors that influence these moments are existence/creation of desired (preferred) status, availability of information about new status (new products or versions of the products), related/complementary products for this product may create a need and motives that drive customer.

After the consumer has developed a need/want, he/she starts an information search about the different alternatives that he/she can purchase to satisfy the need/want. It is the second stage so-called information search. He/she will look both internally and externally for this information to help him/her make a decision. An internal information search consists of utilizing information from memory, such as past experiences with the product/service. An external information search is asking friends and family about their experiences with acquiring a new product. They can also research public sources, such as reviews, blogs. Another external information source would be marketing-controlled sources, such as banners, television ads, brochures, etc. The buying decision influenced by different sources is presented in Figure 4.

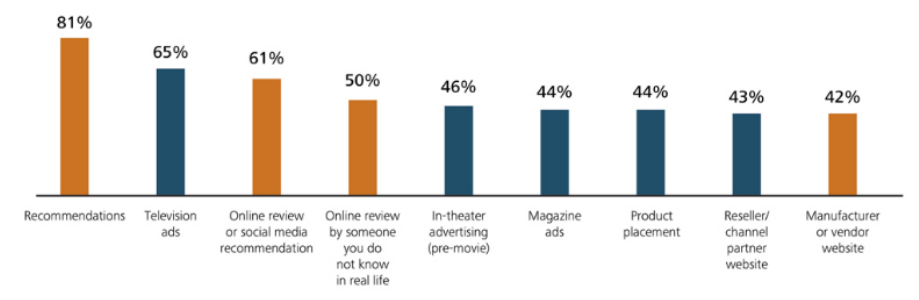

Figure 4: Buying Decision Influence ("Digital Democracy Survey 2015", 2015)

The amount of time dedicated to this step usually depends on the consumer's past experience with buying the product, the risk involved and the level of interest. Once consumer created a set of alternative products to choose from, he/she has created an evoked set. This set consists of the most preferred alternatives. Once the evoked set has been decided upon, the consumer will then conduct final research to further shrink his/her choices ${ }^{1}$.

The process of looking for information, in this case, is a moment that matter for consumers. Marketers have to catch it and provide a relevant description of the product, promotions, etc. Also, recommendations from friends and family and reviews from other consumers will be taking into account. Moreover, previous experience of using the product or similar one and personal experiments while searching (testing the samples) will influence the process.

At the third stage of evaluating alternatives, a consumer may ask her/himself questions like: "Do I actually need the product?" Are there alternatives out there? Is the original product that bad? Usually, the consumer chooses one the most important attribute based on which he/she will make a final decision or using cut-off method (e.g., price, quality, brand, etc.). Here moments that matter could be emotional connections/experiences with products, surrender to advertising/marketing campaigns. For marketers on this step, it is important that a consumer is aware of their brand during the evaluation

${ }^{1} \mathrm{http} / / /$ study.com/academy/lesson/understanding-the-consumerdecision-making-process-a-marketing-must.html 
process and ideally knows the attribute based on what the consumer makes his/her buying decision. The process on this stage is individual for a consumer as he/she is looking for the best deal. A meaning of the best deal based on attributes that are more relevant to each consumer, it could be price, quality, brand, product positioning, a place where to buy (location), consequences of using the product, etc.

At some point, consumer stops to evaluate evoked set and switches to buying process - fourth stage: purchase. Once a consumer chooses which brand to buy, he/she must still implement the decision and make the actual purchase. Also at the beginning consumer may make a purchase intention to buy a certain product, but don't close a deal. Additional decisions may be needed - factors that influence, such as when to buy, where to buy, and how much money to spend. Often, there is a time delay between the formation of a purchase decision and the actual purchase, particularly for complex purchases such as automobiles, personal computers, and consumer durables. For nondurable products, which include many lowinvolvement items such everyday goods; the time between the decision and the actual purchase may be short. At this point, it is critical to hook the consumer in purchase intention and a delay period.

On the last fifth stage - post-purchase (satisfaction or dissatisfaction), consumers evaluate and review the product. Was the product right for the consumer? Did their expectations confirm? If a customer finds that the product has matched or exceeded the promises made and their expectations, they will potentially become a brand ambassador influencing other potential customers in the stage two of their customer journey, increasing the chances of the product being purchased again. The same can be said for negative feedback, which is if emerge at the stage two can restrain a potential customer's journey towards your product ${ }^{2}$. The moments that matter on the last stage is to catch the point if the customer is not satisfied. If the customer is satisfied, then to turn him/her into a loyal customer. Such factor as the product matched or exceeded consumer expectations. Also, follow up activities (after purchase) help to make a loyal customer.

On Figure 5 the self-developed framework of moments that matter and factors influence them is presented. One note to this model should be added. Consumers do not always move in the exact order through the process. The second and the third stages could be repeated a couple of times; also the evaluation stage not in all cases finishes with purchase. It can depend on the type of product, the buying stage of the consumer and even financial status.

Many of the purchase decisions people make as consumers are based on a habitual or routine choice process. For many low-priced, frequently purchased products, the decision process consists of little more than recognizing the problem, engaging in a quick internal search, and making the purchase. The consumer spends little or no effort engaging in external search or alternative evaluation (Belch G. \& Belch M., 2009). So not all of the stages apply to repeated products because the person already has preferences and brand loyalty and it considers like automatic process. Therefore, marketers of products characterised by a routine response purchase process need to get and/or keep their brands in the consumer's evoked set and avoid anything that may result in their removal from it. Marketers of these brands want consumers to follow a routine choice process and continue to purchase their products. This means maintaining high levels of brand awareness through reminder advertising, periodic promotions, and prominent shelf positions in stores.

Also, the paper of Hoyer (1984) provides support to statements above and presents a view of decision-making based on the idea that consumers are not willing to engage in a big deal of decision-making process at the time of purchase when they buy a product repeatedly and it is relatively unimportant. Consequently, consumers apply very quick and effortless choice tactics that provide a satisfactory decision.

Marketers of new brands or those with a low market share face a different challenge. They must find ways to disrupt consumers' routine choice process and get them to consider different alternatives. High levels of advertising may be used to encourage trial period or brand switching, along with sales promotion efforts in the form of free samples, special price offers high-value coupons, etc.

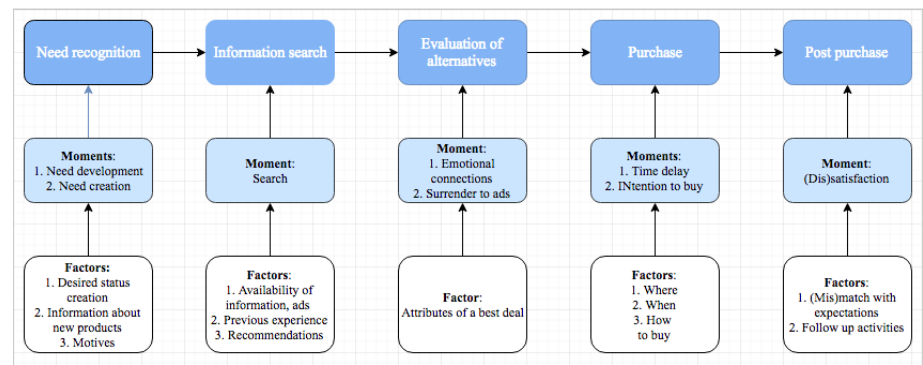

Figure 5: Framework of factors and moments that influence decisionmaking

Nonetheless, the traditional model was criticized, and other scholars add relevant focuses and factors. For example, McAlister (1979) challenged the existing time assumption that product choices are made separately from of each other. The scholar offered a model incorporating dependence among selections of items groups.

Also, Solomon et al. (2006) criticised the traditional model by saying that it is a rational perspective, but people may behave irrationally "such a process is not an accurate portrayal of many of our purchase decisions". Consumers don't go through this sequence whenever they buy something. The authors talk about purchase momentum (impulses that lead to unplanned purchase at the last moment). Also, the authors argue that consumers possess a repertoire of strategies and they choose one according to the situation and the level of effort required, so-called constructive processing. Moreover, they discuss behavioural influence perspective and experimental perspective.

Dhar, Huber \& Khan (2007) also talk about shopping momentum that occurs when an initial purchase provides a psychological impulse that enhances the purchase of a second, unrelated product. The authors propose that the most promising theoretical mechanism comes from Gollwitzer's (1990) theory about implementation and deliberation mindsets. Under this theory, shopping momentum occurs because the initial purchase moves the consumer from a deliberative to an implemental mindset, thus driving subsequent purchases.

\footnotetext{
${ }^{2} \mathrm{http} / / /$ www.professionalacademy.com/blogs-and-advice/marketingtheories---explaining-the-consumer-decision-making-process
} 


\subsection{Variations in Consumer Decision-Making}

Solomon et al. (2006) characterised the decision-making process as the amount of effort that goes into the decision each time it must be made. They found it convenient to think concerning a continuum, which is started by habitual decision-making and ends with extended problemsolving (Figure 6). Many decisions are in the middle and characterised by limited problem-solving.

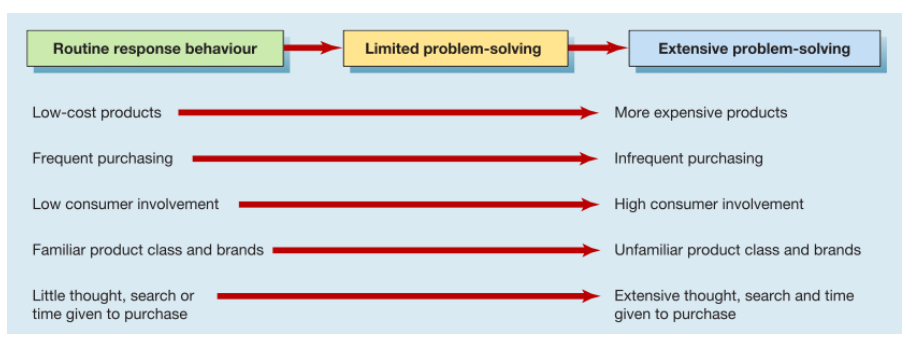

Figure 6: A continuum of buying decision behaviour

Extended problem-solving phase is similar to tradition decision-making process described above. Limited problem-solving is usually more straightforward and simple. People instead use simple decision rules to choose among alternatives. Habitual decision-making refers to decisions that are made with little or no conscious effort - to make choices characterised by automaticity with minimal effort and without conscious control.

Another researcher Armano (2007) has a different non-linear view of the decision process, so-called "The Marketing Spiral" (Figure 7). The author explains it that the spiral amplifies the more the consumer engages, from interaction to engagement, to participation, to conversation, to affinity, to a community. The process of the one cycle may repeat itself adding more cycles to the spiral. But this model did not receive a lot of attention from other researchers so far.

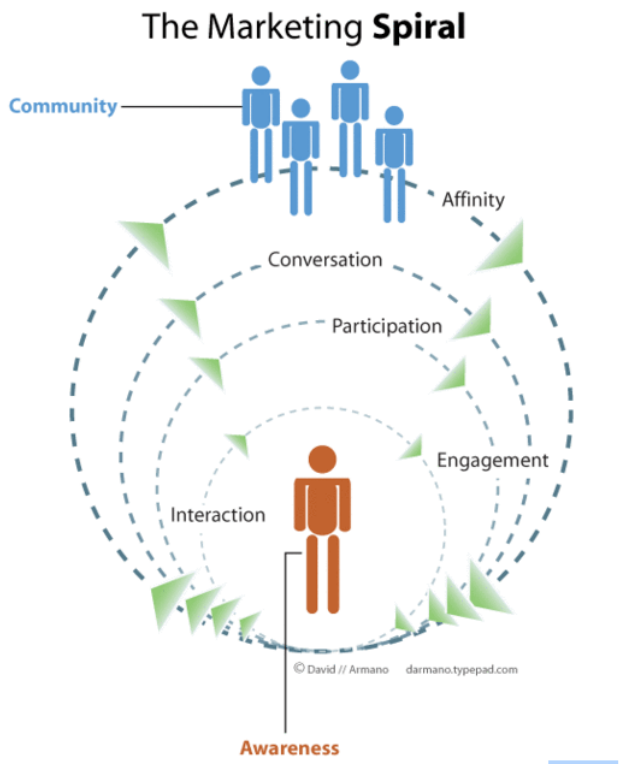

Figure 7: The Marketing Spiral

McKinsey \& Company (2009) supports traditional decision-making model but showing it as a circular process (Figure 8) with four phases: initial consideration; active evaluation, or the process of researching potential purchases; closure, when consumers buy brands; and postpurchase, when consumers experience them.

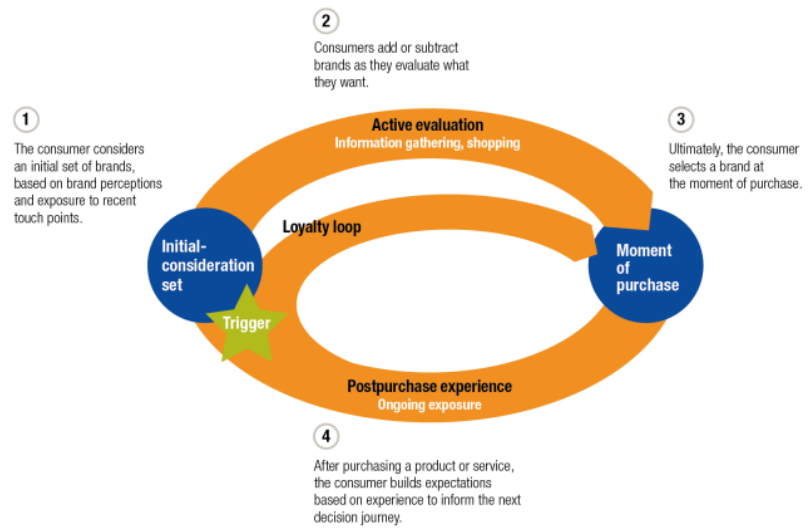

Figure 8: Decision-making process

At the end of this section, a couple of other interesting research will be presented.

A lot of research was done to investigate the how company's brand influences buyer behaviour. One of the papers of Macdonald \& Sharp (2000) describes a replication of the study of Hoyer and Brown on "Brand awareness effects on consumer decision making for a common, repeat purchase product". They examined brand awareness in the consumer choice process. The results of this study support the idea that brand awareness is a dominant choice tactic among other awareness tactics. Choosing from different brands consumers show a preference for the high awareness brand, despite quality and price factors.

Likewise, Heilman, Bowman \& Wright (2000) examined how brand preferences and marketing activities evolve for consumers who are new to a market. The authors developed a theoretical framework that starts with a consumer first purchase in a category and shows subsequent purchases in sequential purchasing stages. The theory is based on the idea that choices made by new to the market consumers are driven by two forces. The first is an information collection stage. The second is a stage in which information collection is extended to less known brands. The authors use a logit-mixture model with time-varying parameters to capture the choice dynamics of different consumer segments. The results of the study show the importance of taking into account a product experience and learning of consumers new to the market when studying the dynamics choice processes.

Back to the traditional model, Belch G. \& Belch M. (2009) discussed the difference between low- and high-involvement in decision making. Their examination of consumer behaviour has looked at the decision-making process from a cognitive orientation. The five-stage decision process model views the consumer as a problem solver and information processor who engages in a variety of mental processes to evaluate various alternatives and determine the degree to which they might satisfy needs or purchase motives. There are other perspectives regarding how consumers acquire the knowledge and experience they use in making purchase decisions. To understand these perspectives, the authors examine various approaches to learning and their implications for advertising and promotion. Consumer learning has been defined as "the process by which individuals acquire the purchase and consumption knowledge and experience they apply to future related behaviour." Two 
basic approaches to learning are the behavioural approach and cognitive learning theory.

Frequently a distinction is made between high and low involvement purchasing, that means that in practice the actual buying process can be less or more reflect this five steps model, depending on the consumer's perceived purchasing risks. The high or low degree of involvement is also an issue of buyer experience. For example, in general, products purchased for the first time require more involvement than repeatedly purchased products (Boyd et al., 2002).

Never should forget about relevant external factors that influence consumer decision-making, such as culture, social class, reference groups, and situational determinants (Belch G. \& Belch M., 2009).

Culture is a one of the complex to study factor. Since there is a change towards a global market, there are different opinions whether there is a convergence in consumption patterns. Lifestyles are focusing on the industrialized world, and similar demographic changes occur in the triad countries. Paper of Yelkur (2002), for example, compares Generation X consumers in the US and France on their buyers' behaviour characteristics such as the importance of brand names, propensity to purchase new products, and price consciousness. Analysis of the results indicates that Generation $\mathrm{X}$ of different countries has significantly different buyer behaviour characteristics. The same results may be transmitted to other countries across the world. Thus there are a lot of unknown issues that have to be explored.

\section{Conclusion}

In this research paper, a literature review in the field of consumer decision-making process was presented, and the papers were discussed for a deeper understanding of state of the art. For a long time, it was a "black box" for marketer what happening in a stage between information search and postpurchase behaviour in buying process. Till now there is no one right answer, but it is possible to follow the tendencies and shed light on some processes. Current trends in the field of consumer behaviour were investigated and presented in the introduction part for catching the flow of the future changes and challenges.

A lot of academic research was done previously, and various theories and models were elaborated by the scholars. The traditional model of fivestaged decision process serves as a base for modern concepts as McKinsey's model (2009). However, it received critics, but nobody can deny it relevance. Using as a foundation the traditional model a framework of influences among "moments that matter" in decisionmaking and factors was developed and demonstrated. It can help to build further research on or prove/reject these relationships.

As the report was progressing marketer might find relevant tips and recommendations for each stage of the new model to use it for a marketing campaign. That may empower to reach success in the market and gain loyal customers.

Regarding methodology gaps in reviewed articles, it was noticed that there should be more sample in the research because nowadays people demand more and more for personalization and it will help to find out common characteristics and interrelations. Also, the key topic now is a difference between generations. How they react on marketing campaigns. As in this century, at least two generations are presented marketers have a complex task to please needs and wants both of them using different approaches.
Moreover, thanks to globalization culture differences are feeling stronger or less depending on context. However, as previous research proved, in different countries consumers behave differently. So it means that not all of the successful marketing instruments in Europe will be so fruitful in Asia.

Less research was done in the sense of the difference in consumer goods. More often scholars talk only about durable and nondurable products. But there is a difference inside these groups of products. Furthermore, less attention pays to services (not products).

Researchers are also beginning to understand the role of controlling the information flow about consumers' decisions, as increased control leads to increased performance. These new insights promise to be particularly important in the new online environments, where controlling the information flow can particularly influence the quality of consumers' decisions, memory, knowledge, and confidence. Research on information structure (the amount of information in a choice set) is also relevant in the new electronic marketplaces, where consumers are regularly faced with information overload when making decisions.

One more interesting direction of future research would be to investigate how the shopping momentum effect is moderated by the nature of the driver item. As a product that considered as "guilty pleasure" (e.g., sweets, cigarettes, alcohol, etc.) would be less cause momentum purchases as standard basket goods, as it is expected.

\section{References}

- Armano D. (2007) The Marketing Spiral, Logic+Emotion

- Belch G. \& Belch M. (2009) Advertising and Promotion: An Integrated Marketing Communications Perspective, 8th ed. Homewood, IL: Irwin.

- Court D., Elzinga D., Mulder S. \& Vetvik O.J. (2009) The consumer decision journey, McKinsey Quarterly.

- "Digital Democracy Survey 2015" (2015) Deloitte LLP.

- Dhar R., Huber J \& Khan U. (2007) The Shopping Momentum, Effect Journal of Marketing Research, Vol. 44, No. 3, pp. 370-378. Crossref

- Engel J.F., Kollat D.T. \& Blackwell R.D. (1968) Consumer behaviour, Holt, Rinehart, Winston, New York.

- Gollwitzer P.M., Heckhausen H. \& Ratajczak H. (1990) From Weighing to Willing: Approaching a Change Decision through Preor Postdecisional Mentation, Organizational behavior and human decision processes 45, 41-65. Crossref

- Hawkins D.I., Mothersbauch D.L. \& Best R.J. (2007) Consumer behavior: Building Marketing Strategy, 10th ed., McGraw-Hill/Irwin.

- Heilman C.M., Bowman D. \& Wright G.P. (2000) The Evolution of Brand Preferences and Choice Behaviors of Consumer New to Market, Journal of Marketing Research Vol. 37, No. 2, pp. 139-155. Crossref

- Howard J.A. \& Sheth J.N. (1969) A Theory of Buyer Behavior, Journal of the American Statistical Assosiation. DOI: 10.2307/2284311. Crossref

- Johson W. (2014) What's the Biggest Influencer in Consumer Purchase Decisions? https://smallbiztrends.com/2014/10/influenceconsumer-purchase-decisions.html, accessed 2 November 2016

- Keeney R.L. (1982) Decision Analysis: An Overview, Operations research, Vol. 20, No. 5, pp. 803-838. Crossref

- Kotler P. \& Keller K.L. (2012) Marketing Management, 14th ed.

- Macdonald E.K. \& Sharp B.M. (2000) Brand Awareness Effects on Consumer Decision Making for a Common, Repeat Purchase 
Product: A Replication, Journal of Business Research 48, 5-15. $\underline{\text { Crossref }}$

- McAlister L. (1979) Choosing Multiple Items from a Product Class, Journal of Consumer Research Vol. 6, No.3, pp. 213-224. Crossref

- Mintzberg H., Raisinghani D. \& Theoret A. (1976) The Structure of "Unstructured" Decision Processes, Administrative Science Quarterly, Vol. 21, No. 2, pp. 246-275. Crossref

- Narayana C.L. \& Markin R.J. (1975) Consumer Behavior and Product Performance: An Alternative Conceptualization, Journal of Marketing Vol. 39, No. 4, pp. 1-6. Crossref

- Nicosia F.M. (1966) Consumer decision processes: marketing and advertising implications, Englewood Cliffs, N.J.: Prentice-Hall.

- Rassuli K.M. \& Harrell G.D. (1990) A New Perspective on Choice, Advances in Consumer Research, Vol. 17, pp. 737-744.

- Sheth J.N., Newman B.I. \& gross B.L. (1991) Why we buy what we buy: A theory of consumption values, Journal of Business Research, Vol. 22, Issue 2, pp. 159-170 doi:10.1016/0148-2963(91)90050-8. Crossref

- Simon H.A. (1959) Theories of Decision-making in Economics and Behavioral Science, The American Economics Review, Vol. XLIX, No. 3.

- "Six Trends That Will Shape Consumer Behavior This Year", (2014), Forbs http://www.forbes.com/sites/onmarketing/2014/02/04/sixtrends-that-will-shape-consumer-behavior-this-year/\#101dc71a7f84

- Smith A.D. \& Rupp W.T. (2003) Strategic online customer decision making: leveraging the transformational power of the Internet, Emerald Insight, Vol. 27, pp. 418-432. Crossref

- Solomon M., Bamossy G., Askegaard S., Hogg M.K. (2006) Consumer Behaviour. A European perspective, 3rd ed. Prentice Hall Financial Times.

- Walsh S. (2016) Five trends that will change consumer behavior in 2016, The Globe and Mail http://www.theglobeandmail.com/reporton-business/small-business/sb-growth/five-trends-that-will-changeconsumer-behaviour-in-2016/article28019355/

- Wayne D. Hoyer (1984) An Examination of Consumer Decision Making for a Common Repeat Purchase Product. DOI: 822-829. Crossref
- Yelkur R. (2002) A comparison of buyer behavior characteristics of US and French Generation X, Journal of Euromarketing, Vol. 12, issue 1 . 